\section{ALA Washington celebrates 50 years}

ALA's Washington Office celebrated 50 years of presence and service with a gala reception and dinner honoring legislative and grassroots library champions.

Carol C. Henderson, executive director, ALA Washington Office, wrote in her greetings, "We're here tonight to celebrate the wisdom of legislators who recognized the need to build up great collections to support research in the specialized fields that keep this country competitive; to support the preservation of brittle books and of rapidly changing new technological formats; to support the recruitment of a diverse and highly educated library profession; to stimulate technological innovation that has encouraged the sharing of library resources across institutional, political, and geographic boundaries for the public's benefit."

Special recognition was given to U.S. Senators Mark Hatfield (R-Ore.), Nancy Kassebaum (R-Kan.), Claiborne Pell (D-R.I.), and Paul Simon (D-Ill.), U.S. Representative Pat Williams (D-Mont.), and Eileen D. Cooke, former director of the ALA Washington Office.

\section{Call for papers-rare \\ books ....}

ACRL's Rare Books \& Manuscripts Section (RBMS) is seeking proposals for papers presenting current research related to the history of manuscript and print culture for presentation at the 1997 RBMS Preconference, which will be held at the Claremont Colleges in southern California, June 24-27, 1997. Selected participants will have 20 minutes to present a paper on completed research or work in progress. Papers will be presented in small group sessions and audience response will be encouraged. Research should not have been submitted for publication or published. Send four copies of the paper proposal no later than September 1, 1996, to: Nora J. Quinlan, Chair, RBMS Preconference Program, c/o Archives and Special Collections, Richter Library, Lniversity of Miami, Coral Gables, FL 331240320; e-mail: nquinlan@ umiami.ir.miami.edu. Proposals should be no longer than one letter-sized page, double-spaced and should include a cover sheet with title, author's name and affiliation, mailing address, phone number, and e-mail address. Applicants should note if they are RBMS members. Faxes and e-mail will not be accepted. Final papers should not exceed 3,000 words. Speakers will be notified by January 31, 1997. Papers will be reviewed based on relevance to the preconference theme, originality, currency, and interest to RBMS members. Submissions from RBMS members will be given priority.

Seminar presentations are also sought and are not limited to the preconference theme. For details contact Elaine Smyth, Louisiana State University Libraries, Baton Rouge, LA 70803; e-mail: notebs@lsuvm.sncc.lsu.edu.

\section{... and "Choosing Our Futures" ...}

July 1,1996 , is the deadline for submitting pro-

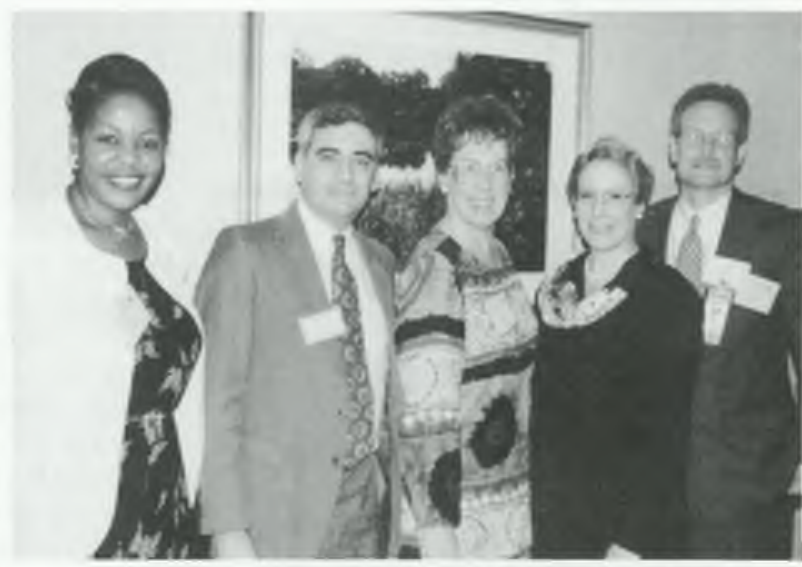

At the ALA Washington Office's gala celebration are members of the ACRL Executive Committee (1 to r): Althea H. Jenkins, William Miller, Patricia Senn Breivik, Helen H. Spalding, and W. Lee Hisle. Not pictured: Susan K. Martin. 


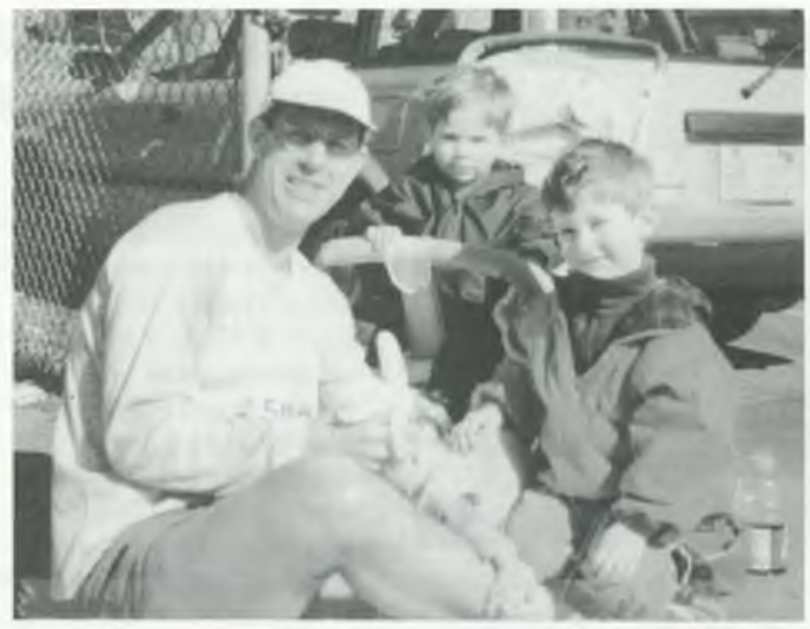

Michael P. Olson, chair of WESS, pauses at mile 22 of the 100th Boston Marathon with his coaches, sons James (middle) and Clancy (right).

posals for papers and panel sessions for ACRL's 8th National Conference in Nashville, April 11-14, 1997. Potential presenters should complete a program proposal application and submit it along with a 250 - to 500-word abstract that completely describes the proposed program. The full "Call for Participation" and proposal form may be found at http://www.ala. org/acrl.html under the National Conference heading and as an insert in the January issue of CERL News. Or call the ACRL office at (800) 545-2433 ext. 2519 to request a copy.

\section{... and popular culture}

Papers are sought for the Popular Culture Association meeting, March 26-29, 1997, in San Antonio, Texas. Those interested in submitting a paper on any aspect of libraries and popular

\section{New! ACRL gifts}

Be the first at your library to own these brand new ACRL items! Too new for pictures! All items will be available at the ALA Store at the New York Annual Conference next month.

- Baseball cap. Black cotton twill cap with embroidered logo featuring "ACRL: Choosing Our Futures."

- Paperweight. Acrylic globe pillar featuring "ACRL: Choosing Our Futures."

- Academic Desk Calendar. Monthly calendar features full-color covers of $C E R I$ Neus. culture should send an abstract of no more than 250 words by September 15, 1996, to Allen Ellis, Associate Professor of Library Services, W. Frank Steely Library, Northern Kentucky University, Highland Heights, KY 41099-6101: (606) 572-5527; fax: (606) 572-5390; e-mail: ellisa@ nku.edu.

\section{WESS chair uses Boston marathon as fundraiser}

Michael P. Olson, chair of ACRL's Western European Specialists Section and librarian for Germanic collections at Harvard University, completed the 100th Boston Marathon in April in four hours and 30 minutes. Olson used the marathon, his first, to raise funds for the Germanic collections at Harvard's Widener Library.

Olson said, "The entire experience was extraordinary, and I would do it all again in a second. I certainly now have the marathon fever: I next intend to run in Berlin on September 29, in an attempt to qualify for the 101st Boston." (The Berlin marathon immediately precedes the Frankfurt Book Fair which Olson attends annually.)

Olson recently established two endowments to support Harvard's Germanic collections: the Eva and Clarence Olson Germanic Book Fund, in memory of his parents who supported him in his Germanic studies from high school through a Ph.D. from UCLA, and the Friends of the Harvard Germanic Collections Book Fund. Olson had asked for donors to sponsor him in the race at $\$ 100$ per sponsorship and estimates that the marathon will contribute $\$ 10,000$ $\$ 25,000$ to the Germanic collections' fundraising efforts.

Olson estimates that about 14 percent of the nearly 13 million volumes in the University Library are Germanic by language making the Library of Congress the only institution with holdings of comparable stature elsewhere in the world. However, Olson feels that much more should be collected: "I've always got this fishing-net mentality. You have to bring the materials in, process them, and let scholars determine whether they're worthy of research."

For details on sponsoring Olson's marathon run or joining the Friends of the Harvard Ger- 
manic Collections, contact Olson at Widener 197, Harvard University Cambridge, MA 02138; e-mail: olson@fas.harvard.edu; (617) 495-2426; fax: (617) 495-0403.

\section{"Choosing Our Futures" open for discussion at Web site} "Nearly all academic librarians agree that academic libraries have to change in order to respond successfully to the new realities of the higher education environment,

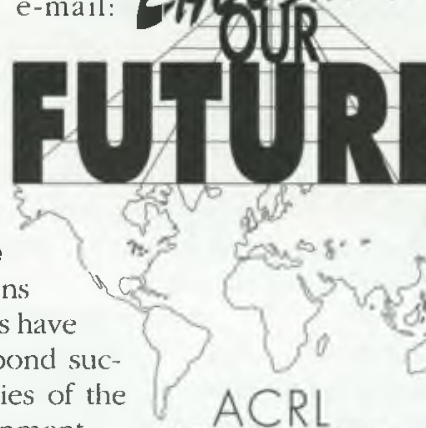

8ih National Conference rapidly developing information and telecommunications tech-nologies, and the crisis in scholarly communications. But there is little agreement on what must change, how the changes will take place, how fast the changes must occur, and how much change is necessary."

Now you have an opportunity to voice your opinion on how libraries will change in the future. The above abstract is from "Choosing Our Futures," an article

\section{C\&RL exchanges articles with German counferpart}

Seeking to give American librarians a sense of the intellectual vitality of librarianship beyond our borders, College $\&$ Research Libraries has undertaken an article exchange project with its German counterpart, ZEITSCHRIFT FÜR BIBLIOTHEKSWESEN UND BIBLIO$G R A P H I E(Z / B B)$. Twice now the officers of the Germanist Discussion Group of ACRL'S Western European Specialist Section (WESS), together with at representative from the CERL Board, have selected an article from $Z F B B$ for publication by CGRL.

The first, "Secret Dissertations in the German Democratic Republic," by Wilhelm Bleek and Lothar Mertens (CERL, September 1995) combined 1992 and 1994 ZfBB pieces on the recent discovery that the government of the GDR had deemed thousands of dissertations too sensitive to list in indices, and, with the compliance of universities and libraries, had removed them physically and expunged them bibliographically. The article was translated by WESS member John Cullars (University of Illinois-Chicago) on a volunteer basis.

This year Nancy Boerner (Indiana University), also a member of WESS, translated Ingo Kolasa's article on the looting of German books by Soviet forces at the end of World War II. This study of the thorny issues that are now the focus of extremely difficult negotiations between German and Russian librarians and government officials will appear in the September 1996 CERL.
The $Z f B B$, in turn, published in its January/February 1996 issue a translation of Barbara M. Wildemuth and Ann L. O'Neill's "The 'Known' in Known-Item Searches: Empirical Support for User-Centered Design" (CERL, May 1995). An editorial note expresses the hope that the article exchange will "promote mutual dialogue and share reflections and experiences." It may not be a coinciclence that CERL chose articles on libraries as they relate to Germany's difficult history, whereas the Germans selected an article that was technical in its focus, each drawn to and drawing on the perceived strength of the other's professional and intellectual traditions.

It would clearly be desirable for this project to be adapted to publications from other countries. And since Europeans are more likely to read English than the other European languages, it is fair to clain that with this exchange CERL is making the work of European librarians more available not only to their American colleagues but to one another. The bureaucratic hurdles in such an enterprise may seem formidable, but if the desire to make the project work is there, they are definitely surmountable. Finding volunteer translators with the necessary skill and generosity is another matter, and on this score one can only say that CERL has been, so far, very fortunate indeed.-Stephen H. Lebmann, University of Pennsyluania, lebmann@pobox. upennedu. 


\section{More ACRL events in New York}

The May 1996 issue of CERL News contained an insert listing ACRL programs, meetings, and special events taking place at the Al.A Annual Conference in New York. This brief list adds to those already published.

ACRL Anthropology and Sociology Section (ANSS) Twenty-fifth Anniversary Celebration/Reception. Monday, July 8, 6:00-7:30 p.m. at the John Jay College of Criminal Justice, 899 Tenth Ave., New York.

ANSS Tour of the American Museum of Natural History Library. Tuesday, July 9, 10:00 a.m.-12:00 noon. The tour will include the reference area, rare hook room, archives, art and memorabilia collection, and conservation laboratory, as well as storage areas and the digitization project for collection management in the Anthropology Department. The tour, which will be followed by a reception, is limited to the first 60 participants who advance register. To register send $\$ 5$ (checks made payable to Maija Lutz) to Maija M. Lutz, Tozzer Library, Harvard University, 21 Divinity Ave., Cambridge, MA 02138.

ACRL Instruction Section and LIR'T to honor Martin Raish. Monday, July 8, 9:30 a.m. Martin Raish, creator and moderator of the BI-L listserv, will receive a special certificate of recognition and appreciation at the joint IS/LIRT meeting. The certificate recognizes Raish's critical contributions to more than 2,300 BI-L listserv subscribers. The focus of $B I-L$ is on library instruction, with sulsstantive discussions, requests for advice and handouts, and reports on activities, new programs, and classrooms.

ACRL International Relations. Saturday, July 6, 9:00 a.m. Guests are welcome to the committee-led discussion on international librarianship that will look at questions such as: How can American librarians understand and make use of the experience of librarians in other countries? What is the "political culture" of libraries? How does the planned Glohal Information Infrastructure affect American and other librarians?

ACRL Science and Technology Section General Discussion Group. Sunday, July 7 , 2:00-4:00 p.m. Julie Arnott, SOLINET Preservation Services Manager, and Tom Clareson, AMIGOS Preservation Services Manager, will join the group.

ACRL Western European Specialists Section Scandinavian Discussion Group. Sunday, July 7, 4:30-5:30 p.m. Will discuss grant-funded, collaborative access and preservation projects focusing on the work at Cornell's Fiske Icelandic Collection.

in the May issue of College $\&$ Research Libraries, written by Carla J. Stoffle, Robert Renaud, and Jerilyn R. Veldof. The article and commentaries on it (provided by Susan Lee, Bonnie Jeuergens, and Richard Hume Werking) appear in an interactive form on the ACRI 8th National Conference Homepage at http://www.ala.org/acrl html.

"Choosing Our Futures" is the theme of the ACRL 8th National Conference, to be held in Nashville, April 11-14, 1997. Conference organizers would like your input on the future of libraries. Visit the conference homepage and follow the instructions for posting your comments and opinions.

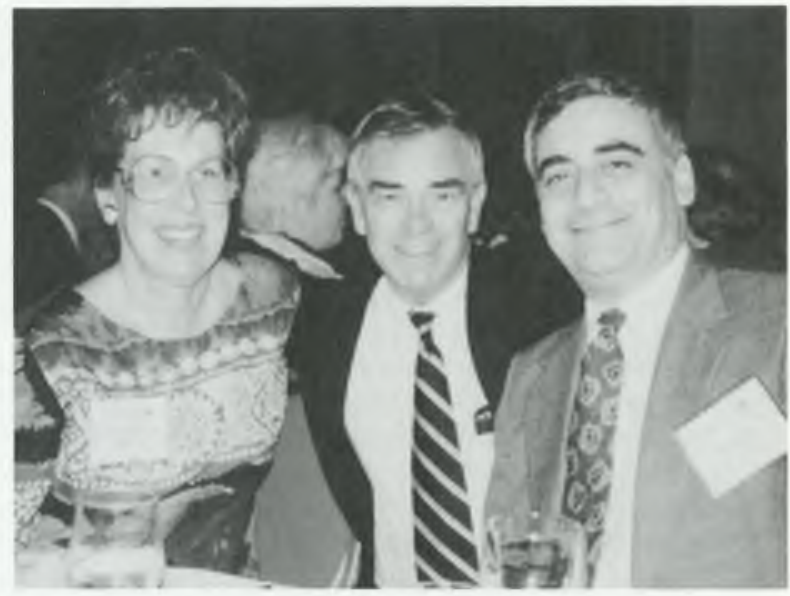

Patricia Senn Breivik (1) and William Miller ( $r$ ) enjoy the gala for the ALA Washington Office with Ralph Russell (center), ACRL's 1996 Academic/Research Librarian of the Year. 


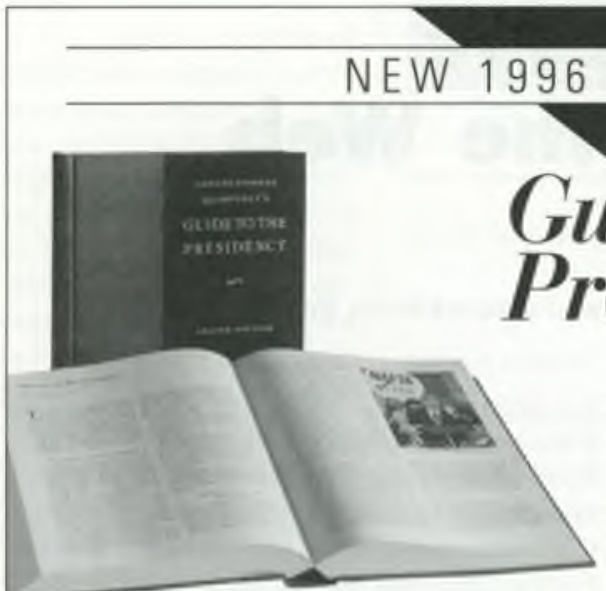

The NEW second edition of Congressional Quarterly's highly acclaimed reference, Guide to the Presidency, is now expanded into two volumes and fully updated to cover the Bush administration and Clinton presidency through 1996. Guide to the Presidency examines the presidency's origins and history... presidents
EDITIONS!
2ND EDITION

Michael Nelson, Editor

Discover how the U.S. presidency has evolved through crisis, challenge, and change in over 200 years.

and their legacies... day-to-day governing... campaigns and elections... political parties, interest groups, the media... and new challenges facing the presidency on the eve of the 21 st century.

2-volume set. App. 1.700 pages. Hardbound. ISBN 1-56802-018XX \$289.00. Publication: June 1996

\section{Guide to the U.S. Supreme Court}

\section{RD EDITION}

Joan Biskupic and Elder Witt

\section{Follow the Supreme Court and its 200 year history with the most comprehen. sive reference available on the Court.}

The third edition of Congressional Quarterly's classic reference, Guide the the U.S. Supreme Court, is now updated with coverage through the Court's 1995-1996 term, including major cases and recent Court appointments.

Expanded to two volumes, Guide to the U.S. Supreme Court offers readers of all levels the

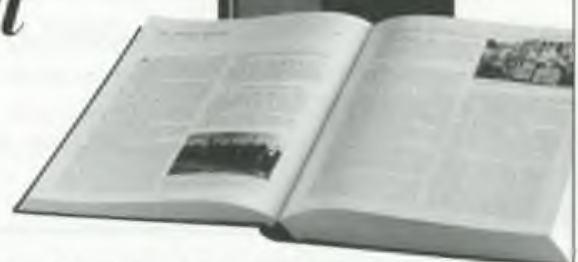

most detailed and thorough examination available of the Court's evolution from 1789 to today, including landmark decisions...the Court's origins and development... its inner workings ... the justices who have served.. and the Court's impact on American society.

2-volume set. App. 1,200 pages. Hardbound. ISBN 1-56802-130-5. Publication: November 1996 Pre-publication price: $\$ 239.00$. List price: $\$ 28900$ 